\title{
Towards an international health market with the European Court
}

Martinsen, Dorte Sindbjerg

Published in:

West European Politics

DOI:

http://dx.doi.org/10.1080/01402380500311806

Publication date:

2005

Document version

Early version, also known as pre-print

Citation for published version (APA):

Martinsen, D. S. (2005). Towards an international health market with the European Court. West European Politics, 28(5), 1035-1056. https://doi.org/10.1080/01402380500311806 


\title{
Towards an Internal Health Market with the European Court
}

\author{
Dorte Sindbjerg Martinsen \\ West European Politics (2005), Vol. 28 (5), 1035-1056 \\ http://www.tandfonline.com/doi/abs/10.1080/01402380500311806\#.VCl4o7ccS70
}

\begin{abstract}
This article examines the process through which a European healthcare dimension has been established and which has gradually extended the rights of European patients to cross-border healthcare. The integrative course has been charted by the legal activism of the European Court of Justice, whereas political voice has largely been absent. Judicial activism alone has applied the principle of the free movement of services to the policy field of healthcare, and thereby further energised the process. The political impact of this specific process of integration through law is, however, clear. The dynamic evolution of Community law has increasingly challenged the national instrument to retain health supply within own borders. Furthermore, the position of the European patient has been empowered by new individual rights, emanating from a supranational locus of rights against which the discretion exerted by national authorities can be challenged. Through the indeterminacy of European rules, open to continuous contestation and clarification, healthcare institutionalisation has proceeded and the European Union has extended into the core of the welfare state.
\end{abstract}

The path to European healthcare integration has by no means represented a linear expansion of Community competencies, but an integration process marked by contradictions. That Europe ever came to regulate national healthcare has not occurred as an output of rational political decisionmaking, but rather, as a 'side-effect' of how the European Court of Justice gradually conferred a 'supreme' status to the free movement provisions in the EU legal construct and in this way interfered in virtually all areas of national law and policy (Maduro 1999). Since 1998, however, the impact of these 'side-effects' on national healthcare policies has taken a turning point, making irrevocably clear that the policy domain of healthcare is hardly an "island beyond the reach of 
Community law". ${ }^{2}$ Whereas politicians in the late 1990s spoke very strongly against the jurisprudence of the Court ${ }^{2}$, today it appears to be a materialised fact that the European Union has also attained a healthcare dimension, and that the European patient is empowered by a set of rights to cross-border treatment.

This article investigates how judicial decision-making has gradually extended the right to intraEuropean healthcare. It does so by examining the bits and pieces of institutional change, whereby dynamic judicial interpretations of Community law have integrated the 'less likely, ${ }^{3}$ policy field. By examining the expansion of Community competencies through law, the article inherently addresses the role of politics, and thus the contested relationship between law and politics (Alter 2001).

The examination will demonstrate a Court that, through its teleological or purposive means of interpreting the content and scope of Community law, at times overtakes the role of politics. It will depict a Court that applies a systematic method of 'gap-filling', where the line of a legal principle is gradually being drawn and extended to a new policy field. The full scope and consequence of the legal deduction is revealed from case-to-case and, in the case of healthcare, evidently remains in a formative process.

"A common tactic is to introduce a new doctrine gradually: in the first case that comes before it, the Court will establish the doctrine as a general principle, but suggest that it is subject to various qualifications; the Court may even find some reason why it should not be applied to the particular facts of the case. The principle, however, is now established. If there are not too many protests, it will be re-affirmed in later cases; the qualifications can then be whittled away and the full extent of the doctrine revealed" (Hartley 1998: 79).

\footnotetext{
${ }^{1}$ As formulated by the Advocate General Tesauro in the 1998 cases of Decker and Kohll, which will be further examined below.

${ }^{2}$ In the wake of the Decker/Kohll judgements, the former German Minister of Health, Horst Seehofer, argued that the member states had to overturn the rulings of the Court by a Treaty amendment, and that Germany would not comply with the rulings (Langer 1999; Børsen 7. May 1998). He further argued that the Decker/Kohll procedure marked a revolutionary turn and that if Germany adopted the premises, it would pose a long-term threat to the sustainability of the German health system (Spiegel 17/98; Schaaf 1999: 274; Eichenhofer 1999b: 114).

${ }^{3}$ Placed on a continuum between the 'least-likely' and 'most-likely' cases, the case of healthcare represents a 'lesslikely' case of integration; not 'least-likely', because the free movement principles are constitutive principles in the construction of the internal market and therefore make up fundamental provisions for market integration. However, it remains 'less likely', because member states maintain the prerogative to organise their healthcare policies, and have repeatedly refused regulation from the European Union. For discussion of the strategic-theoretical purpose of choosing a 'least likely' case, see Eckstein (1975).
} 
This path dependent manner of legal institutionalisation, wherein the scope, meaning and impact of a doctrine are incrementally established, accentuates recurring theoretical questions of integration; how could healthcare integration progressively take place and why did politics not restrain such an expansive integrative course, if politically unintended? Among other findings, it will be demonstrated that on the basis of the Treaty as an 'incomplete contract' (Stone Sweet 2004), as well as the complexity and insufficiency of established rules, the Court enjoys considerable discretion to apply, interpret and clarify the meaning of Community law and policy; and it becomes correspondingly difficult for politics to withstand such legal interpretations of the 'law of the land'.

The following analysis details how the national autonomy to determine the spatial borders of health consumption and supply has been restrained, re-established and compromised anew by Community law. It demonstrates a Court that historically has been politically restrained, but which recently - in the absence of political voice - has been capable of acting both cautiously and ambitiously at one and the same time, thus extending the rights of the European patient.

On the basis of a process-tracing study, five chronologically structured sections will examine in the following how the scope and limits of intra-European healthcare have been drawn over time. Upon this examination, the article will finally examine contemporary patient mobility in the EU and return to the question of political impact and why politics has not reigned in a Court, whose legal reasoning has made the European Union extend to the core of the welfare state.

\section{The Scope and Limits of European Healthcare}

European citizens moving or travelling from one member state to another enjoy a right to immediate healthcare in the other member state as well as to other kinds of publicly financed health treatment, provided that they have been authorised beforehand by the competent national institution. ${ }^{4}$

Apart from compromising the territoriality of healthcare, this means that the member states place their healthcare system at the disposal of one another's nationals (Neumann-Duesberg 1999: 25). From the outset, only the migrant worker and his family enjoyed the right to cross-border

\footnotetext{
${ }^{4}$ Regulation (EC) 883/2004 of the European Parliament and of the Council of 29 April 2004 on the coordination of social security systems. Official Journal L 166, 30/04/2004 P. 0001-0123.
} 
healthcare, ${ }^{5}$ however, this right has been gradually expanded to the point where it was extended to all European citizens in 2004, as well as to formally cover legally residing third country nationals. ${ }^{6}$

The questions of whether and under what conditions healthcare ought to be authorised abroad has comprised a bone of contention between national healthcare institutions, national courts and the European Court of Justice. On the one hand, national authorisation policies ${ }^{7}$ constitute the most powerful means to restrict healthcare within own borders and are indeed instruments of national control. On the other hand, the evolution of EU law has proven that authorisation policies are not autonomously defined, but challenged, justified and compromised by Community law.

\section{National Discretion Restrained, but Reaffirmed}

The scope and meaning of cross-border healthcare rights, granted by the Community secondary legislation, ${ }^{8}$ was challenged in the late 1970 s by the Pierik cases. ${ }^{9}$ The European Court was requested to rule on the situation of Mrs. Pierik, who resided and held her social insurance in the Netherlands, but went for hydrotherapy treatment in Germany. The competent Dutch health insurance institution subsequently refused to reimburse the costs of the treatment, since hydrotherapy was not a treatment offered by the public health insurance in the Netherlands, and since prior authorisation to the treatment had not been granted.

The Pierik judgements indeed became controversial rulings. The Court disregarded the far-reaching consequences, which were depicted in the submitted opinions from the member states. For example, the British government remarked that if Community law obliged national health insurance

\footnotetext{
${ }^{5}$ From the outset, it was only the worker 'stricto sensu', i.e. the market citizen holding an employment contract, who enjoyed the right to intra-European healthcare (Everson 1995; Shaw 1997; Martinsen 2003).

${ }^{6}$ Third country nationals are covered by Council Regulation (EC) No 859/2003 of 14 May 2003, but have no right to free movement according to Community law. On the special status of third country nationals, see Martinsen (2003).

${ }^{7}$ Authorisation policies determine that the national healthcare system only reimburses the costs of non-acute treatment carried out abroad if that treatment has been authorised beforehand.

${ }^{8}$ As laid down by Regulation (EEC) No. 1408/71 of the Council of 14 June 1971 on the application of social security schemes to employed and self-employed persons, and to the members of their families moving within the Community.

${ }^{9}$ Case 117/77, 16 March 1978. Bestuur van het Algemeen Ziekenfonds Drenthe-Platteland v. G. Pierik. ECR 1978, page 825 \& Case 182/78, 31 May 1979. Bestuur van het Algemeen Ziekenfonds Drenthe-Platteland v. G. Pierik. ECR 1979, page 1977 .
} 
institutions to pay for the costs of treatment abroad, which domestic health policies did not provide for, then the;

"scope of those provisions would be distorted since they would have the effect of creating an independent social security law of the Community instead of merely coordinating the social security law of the member states" (ECR 1978, p. 831, emphasis added).

The Court overruled these political warnings on harmonisation effects, laying down that regardless whether or not the treatment was part of the national health package, a competent institution was obliged to authorise treatment in another member state if the foreign treatment had been recognised as necessary and effective.

"The duty laid down in the second subparagraph of Article $22(2)^{10}$ to grant the authorisation required under Article 22 (1) (c) covers both cases where the treatment provided in another Member State is more effective than that which the person concerned can receive in the Member State where he resides and those in which the treatment in question cannot be provided on the territory of the latter State" (Para. 22 of Pierik I, emphasis added).

In the case of the Pierik judgement, the Court clarified that in the relationship between Community law and national authorisation policies, the decisive element determining whether or not the patient was entitled to foreign treatment at public expense was that person's state of health, and not whether the relevant treatment was part of the healthcare scheme in the individual member state. The decisions thus potentially opened up for the possibility of 'regime shopping' (Ferrera 2003: 634). The judgements stand as the very early recognition of the patient's right to travel within the Community for healthcare. By limiting the discretionary authorisation power of the competent institution, the long-term consequence could have been harmonisation at the highest level. This was a possible scenario, since patients shopping around Europe at the expense of their competent state would indirectly encourage, and perhaps even oblige, member states to establish the same kind of treatments (Eichenhofer 1999: 52).

Such 'top-up' effects of the Pierik cases never happened, however, due to the political reaction. The prompt Council reaction to the legal deduction proves that a judicial doctrine in formation ultimately must be politically supported, and that if individual litigation proceeds excessively in terms of financial and political implications, the member states will seek to mobilise joint action against the Court's interpretative course. In this case, the Council successfully re-established the

\footnotetext{
${ }^{10}$ I.e. of Regulation $1408 / 71$.
} 
discretionary power of national authorities by unanimously amending the provision in secondary legislation, the meaning of which had been expanded by the interpretation of the Court. ${ }^{11}$ The amendment directly corrected the interpretations by the Court and the new provision clarified political intentions, thus re-balancing competencies in favour of the member state. Thus reformulated, the provision specified that the competent institution was obliged to authorise treatment abroad, only when it was administratively and medically considered necessary, and only when that treatment was part of the national healthcare package.

Having initiated the establishment of a supranational system of healthcare beyond the control of the member state, which could fundamentally compromise the ability of member states to decide on the content of national healthcare, the Court was politically restrained. For almost two decades, national authorisation policies seemed sacred, with an established balance between national and Community competencies. That was prior to the Decker/Kohll ruling of 1998.

\section{Authorisation Policies before the Internal Market}

The established order between national health policy and Community law was seriously upset by the rulings of Decker ${ }^{12}$ and Kohll $^{13}$ in 1998, and not least by their aftermath. The Decker/Kohll cases were landmark rulings, clarifying that the Community principles regarding the free movement of goods and services also regulate national health policies. The importance of the rulings was stressed widely by academics and national presses, whereas the majority of member states met the judgements with official silence (Eichenhofer 1999b: 102; Eichenhofer 2001: 237; Hervey 2000: 40; Kötter 2000: 28; Maydell 1999: 9; Mossialos et al. 2001: 45; Novak 1998: 366; Palm 2000: 105). Their full impact remains difficult to detect, since subsequent cases provide answers to some of the questions raised by the Decker/Kohll procedure, while they pose new questions themselves.

\footnotetext{
${ }^{11}$ Only two years after the Pierik ruling, the member governments adopted Regulation 2793/81 of 17 September 1981 , amending Regulation 1408/71. The amendment inserted a new Article 22 (2) 2 in Regulation 1408, which widened the discretion that the competent health insurance institutions of the member states enjoyed when issuing authorisation. The new provision 22 (2) 2 laid down that national authorities were only obliged to grant authorisation when; "the treatment in question is among the benefits provided for by the legislation of the member state [...] and where he cannot be given such treatment within the time normally necessary for obtaining the treatment in question in the Member State of residence"(emphasis added).

${ }^{12}$ Case C-120/95, 28 April 1998. Nicolas Decker v Caisse de Maladie des Employés de Privés. ECR 1998, page I-1831.

${ }^{13}$ Case C-158/96, 28 April 1998. Raymond Kohll v Union des Caisses de Maladie. ECR 1998, page I-1931.
} 
Furthermore, a collective political response codifying the relationship between the Community's free movement provisions and national healthcare policies remains called for.

The cases of Decker and Kohll concerned two Luxembourg citizens who went abroad to purchase a pair of spectacles and dental treatment, respectively. They subsequently presented claims for the costs to be reimbursed by their health insurance in Luxembourg, although prior authorisation had not been granted. ${ }^{14}$ The national authorities refused reimbursement, since Decker had not obtained prior authorisation, and since the Treatment received by Kohll's daughter was not considered urgent and could have been obtained in Luxembourg.

That the Decker and Kohll cases were attributed high political and legal importance is clear from the many member states that delivered opinions together with Luxembourg. Apart from Luxembourg, eight governments stated an opinion in the cases. ${ }^{15}$ The joint viewpoint was that the free movement principles concerned had no influence on the policy field of social security. The governments further argued that the prior authorisation procedure was a necessary instrument to:

- Maintain the financial equilibrium of the healthcare system;

- Ensure the general quality of the health goods and services provided, thus protecting public health;

- Ensure the maintenance of balanced medical and hospital services available to all.

The ECJ initiated its line of reasoning by stating "Community law does not detract from the powers of the Member States to organise their social security systems" (para. 17 Kohll; para. 21 Decker). That being admitted, the Court nonetheless dismissed that the basic principles of free movement should not apply to the policy field of social security (paras. 20-21 Kohll; paras. 24-25 Decker). The legal reasoning thus made clear that member states did retain the authority and discretion to organise the policy domain of social security, but only within certain limits (Palm et al. 2000: 70). Furthermore, the ECJ dismissed the national justifications for the authorisation procedure, concluding that the Luxembourg requirement of prior authorisation represented an unjustified

\footnotetext{
${ }^{14}$ Both treatments are benefits reimbursed by the Luxembourg sickness insurance fund when bought within Luxembourg.

${ }^{15}$ In the Decker case, Luxembourg, Belgium, Germany, Spain, France, the Netherlands, and the United Kingdom gave written opinions. In the Kohll case, Greece, the United Kingdom, Germany, France, and Austria joined Luxembourg.
} 
barrier to the principles of free movement, which discouraged insured persons to seek health goods and services beyond national borders (para. 36 Decker; para 35 Kohll).

The intermediate outcome of the now-famous rulings was a new set of questions that called for administrative, political, and legal responses (Palm et al. 2000: 105; Mossialos et al. 2001: 48). What autonomy did the member states now have to condition access to healthcare abroad? Did the conclusions apply to all of the different social security systems, or only to systems of reimbursement such as in Luxembourg $?^{16}$ Did the conclusions also apply to hospital services?

While awaiting a political reaction, new cases were brought before the Court.

\section{National Discretion Compromised}

The Decker and Kohll cases concerned services provided outside of the hospital sector. Furthermore, the cases treated the specific Luxembourg health insurance system, which is characterised by its subsequent reimbursement of treatment costs. Since the Decker-Kohll rulings, the scope of the established procedure has been questioned, and further legal clarification been awaited.

The Smits-Peerbooms ${ }^{17}$ case of July 2001 clarified some of the aspects left open, while raising different ones. The cases treated the rights of Mrs. Smits and Mr. Peerbooms and, like the Pierik case, addressed Dutch authorisation policies. The competent Dutch institution refused to reimburse the costs of a multidisciplinary treatment that Mrs. Smits had received in Germany on the grounds that satisfactory and adequate treatment was available in the Netherlands. Furthermore, the competent Dutch institution found that there was no medical justification for the treatment, since it was not proven to be advantageous to the treatment supplied in the Netherlands. The German

\footnotetext{
${ }^{16}$ Healthcare supply in EU-15 diverges significantly. Luxembourg, Belgium and France provide healthcare as social insurance, where the competent institutions reimburse the costs of care. Germany, France and the Netherlands also have social insurance schemes, but contracted providers offer treatment as benefits-in-kind. Finally, the UK, Ireland, Denmark, Sweden, Finland, Spain, Portugal, Italy and Greece provide public healthcare through their national health services, which mainly offer treatments as benefits-in-kind (Langer 1999; Palm 2000; Martinsen 2004).

${ }^{17}$ Case C-157/99, 12 July 2001. B.S.M. Geraets-Smits v Stichting Ziekenfonds VGZ and H.T.M. Peerbooms v Stichting CZ Groep Zorgverzekeringen. ECR 2001, page I-05473.
} 
treatment was regarded as 'non-standard' by the Dutch sickness insurance. Mr. Peerbooms was, on the recommendation of his Dutch neurologist, referred to an Austrian hospital to undergo special therapy involving intensive neurostimulation. Intensive neurostimulation is only used on an experimental basis in the Netherlands, and Mr. Peerbooms did not fulfil the criteria to receive the treatment in his own country. While the Austrian treatment proved to be quite effective for Mr. Peerbooms, the competent Dutch institution refused to reimburse the costs of care. The reimbursement request was turned down with reference to the fact that Dutch health policy considered the therapy to be experimental, and that no scientific evidence of its effectiveness was provided.

Both the cases of Smits and Peerbooms concerned treatments that were not considered 'standard' by Dutch health policy, and consequently were not covered by the national social security system. According to Dutch law, prior authorisation for treatment abroad is granted if two conditions are fulfilled; 1) the proposed treatment must be among the benefits for which the competent institution assumes responsibility, meaning that the treatment must be regarded as "normal in the professional circles concerned", and 2) that the required treatment is necessary and not available without "undue delay" in the Netherlands.

The Court was requested to clarify three aspects of the relationship between Community law and national health policy: did the freedom to provide services apply to hospital care? And, if so, did the national prior authorisation policy violate the Treaty provision? Finally, if affirmed, could the authorisation system still be justified?

The cases of Smits and Peerbooms received great political attention. No less than 10 member governments submitted their opinions to the Court. ${ }^{18} \mathrm{~A}$ basic viewpoint held by the member states was that hospital care did not constitute a service within the meaning of the Treaty, i.e. within the Treaty's article 50, and therefore the free movement provision did not apply. ${ }^{19}$ The opinion advanced was that, since hospital care represented an in-kind service, free of charge, it was not an

\footnotetext{
18 The member states delivering opinions were the Netherlands, Belgium, Denmark, Germany, France, Ireland, Portugal, Finland, Sweden, and the United Kingdom. Furthermore, the EEA states of Iceland and Norway gave opinion.

${ }^{19}$ The Treaty's article 50 states 'Services shall be considered to be 'services' within the meaning of this Treaty where they are normally provided for remuneration [...] 'Services' shall in particular include: (a) activities of an industrial character, (b) activities of a commercial character, (c) activities of craftsmen, (d) activities of the professions.[...]”
} 
economic activity as a service within the meaning of the Treaty would necessarily be, where remuneration was part of the exchange (paras. $48-49$ of the judgement). ${ }^{20}$

The Court did not uphold the national argument. To the contrary, it was stated as settled case-law that medical activities fell within the scope of the Treaty's article 50, without distinction as to whether the services were provided inside or outside of a hospital environment (para. 53 of the judgement). ${ }^{21}$ The Court thereby confirmed that the Decker/Kohll procedure applied, in principle, to all forms of healthcare, whether based on in-kind benefits or reimbursement (Mossialos et. al. 2001: 49).

The ECJ subsequently made clear that the requirement to apply for prior authorisation constituted a barrier to the freedom to provide services (para. 69 of the judgement). ${ }^{22}$ However, the Court also found that prior authorisation could in fact be justified as a 'necessary and reasonable' instrument to guarantee a balanced and assessable hospital sector, which depended on planning and contracting (paras. 76-80 of the judgement). The conclusions of the Court were clear and did not interfere with the basic right of the member state to maintain prior authorisation as a means of control,

"[...] it is clear that, if insured persons were at liberty, regardless of the circumstances, to use the services of hospitals with which their sickness insurance fund had no contractual arrangements, whether they were situated in the Netherlands or in another Member State, all the planning which goes into the contractual system in an effort to guarantee a rationalised, stable, balanced and accessible supply of hospital services would be jeopardised at a stroke" (para. 81 of the judgement, emphasis added).

However, the subsequent line of reasoning conditioned the use of that same means of control, instead bringing the rights of the European patient into focus. That the legal reasoning compromised the discretionary autonomy of the competent institution and, in consequence, empowered the position of the patient, is clear from the legal emphasis on that, for a prior authorisation scheme to be justified, it must,

\footnotetext{
${ }^{20}$ The member states relied in particular on the case of Humbel, paras. 17 to 19 [Case 263/86, 27 September 1988. Belgian State v René Humbel and Marie-Thérèse Edel. ECR 1988, p. 5365], and the case Society for the Protection of Unborn Children Ireland, para. 18 [Case C-159/90, 4 October 1991. The Society for the Protection of Unborn Children Ireland Ltd $v$ Stephen Grogan and others. ECR 1991, p. I-4685].

21 The Court referred among other case-law to case C-159/90 Society for the Protection of Unborn Children Ireland, para. 18, and Kohll, paras. 29 and 51.

${ }^{22}$ Among other cases, the Court referred to Kohll, para. 35 on this point.
} 
"be based on objective, non-discriminatory criteria which are known in advance, in such a way as to circumscribe the exercise of the national authorities' discretion, so that it is not used arbitrarily. [...] Such a prior administrative authorisation scheme must likewise be based on a procedural system which is easily accessible and capable of ensuring that a request for authorisation will be dealt with objectively and impartially within a reasonable time and refusals to grant authorisation must also be capable of being challenged in judicial or quasi-judicial proceedings" (para. 90 of the judgement, emphasis added).

The Court furthermore clarified that the decision on what constitutes a "normal" treatment must be based on "international medical science", and not just on what is the dominant point of view in national medical circles (para. 108 of the judgement). The Court reasoned this part of the conclusion by arguing that if the scientific views on what is a "normal" treatment are determined exclusively from a national medical perspective, it is "likely that Netherlands providers of treatment will always be preferred in practice" (para. 96 of the judgment).

The second Dutch condition for the authorisation of treatment abroad, allowing such authorisation only when the necessary treatment cannot be delivered in the Netherlands without "undue delay", was furthermore interpreted on a non-discriminatory basis by the Court. The ECJ concluded that,

"once it is clear that treatment covered by the national insurance system cannot be provided by a contracted establishment, it is not acceptable that national hospitals not having any contractual arrangements with the insured person's sickness insurance fund be given priority over hospitals in other Member States" (para. 107 of the judgment, emphasis added).

In other words, once it is evident that a treatment cannot be provided by a contracted provider in the Netherlands, the Court hereby clarified that the Dutch sickness fund cannot favour a noncontracted, i.e. private, provider established in the Netherlands over a provider in another member state (Mossialos et al. 2001: 53). When purchasing treatment beyond the contracted providers, the principle of non-discrimination rules.

Furthermore, when determining whether an effective treatment can be provided without "undue delay" from a contracted provider,

"the national authorities are required to have regard to all the circumstances of each specific case and to take due account not only of the patient's medical condition at the time when authorisation is sought but also of his past record" (para. 104 of the judgement). 
With the Smits-Peerbooms ruling, the Court confirmed and extended the Decker-Kohll procedure to the hospital sector as well as to social security systems based on benefits-in-kind. The conclusions of the Smits-Peerbooms case have since been restated in case C-56/01 Inizan. ${ }^{23}$ By restating its previous conclusions in the Inizan case and re-emphasising the non-discriminatory provision, the Court highlights the significance of the patient's position, transparency and legal certainty:

\footnotetext{
"According to the case-law of the Court, in order for such a prior administrative authorisation scheme to be justified even though it derogates from a fundamental freedom such as that in issue in the main proceedings, it is none the less necessary that it be based on objective, non-discriminatory criteria which are known in advance, in such a way as to circumscribe the exercise of the national authorities' discretion, so that it is not used arbitrarily [...] such a prior administrative authorisation scheme must, similarly, be based on a procedural system which is easily accessible and capable of ensuring that a request for authorisation will be dealt with objectively and impartially within a reasonable time and refusals to grant authorisation must also be capable of being challenged in judicial or quasi-judicial proceedings (para. 57 of C-56/01 Inizan, emphasis added).
}

While the Court has confirmed the competence of the member states to control the supply of health services through the instrument of prior authorisation, at the same time it has intervened in the national autonomy to exercise such an instrument. In the absence of political voice, the position of the European patient has been significantly empowered by the Court. In the future, the patient seeking treatment abroad will be able to challenge administrative discretion from national authorities, relying on European law. Granting European citizens the right to try prior authorisation decisions in judicial or quasi-judicial ways suggests that the Court will not tolerate "blanket refusals" from national authorities in the future (Mossialos and Palm 2003: 21). While they essentially justify authorisation policies, the cases of Smits-Peerbooms and the later Inizan case are powerful demonstrations of judicial activism discreetly intervening in, conditioning, and compromising the political and administrative scope of manoeuvre.

\section{The Evolving Internal Market for Non-Hospital Healthcare}

Like the other cases on national healthcare and Community law, the later case of 13 May 2003, C385/99 Müller-Fauré \& Van Riet ${ }^{24}$, was a case in relation to which the majority of member states

\footnotetext{
${ }^{23}$ Case C-56/01, 23 October 2003. Patricia Inizan v Caisse primaire d'assurance maladie des Hauts-de-Seine. ECR 2003, p. 0000.

${ }^{24}$ Case C-385/99, 13 May 2003. Müller-Fauré v Onderlinge Waarborgmaatschappij OZ Zorgverzekeringen and Van Riet v Onderlinge Waarborgmaatschappij ZAO Zorgverzekeringen. ECR 2003, p. I-04509.
} 
submitted opinions. ${ }^{25}$ The Müller-Fauré \& Van Riet case continued the considerations concerning Dutch authorisation policy. The referring social court had, subsequent to the Smits-Peerbooms ruling, been asked whether it wished to continue the case. The national court wanted to maintain its reference, since it found that the Smits-Peerbooms ruling did not consider the specific characteristics of the Netherlands sickness insurance system, being a benefit-in-kind system based on agreements between the national health insurance and contracted providers.

The Müller-Fauré \& Van Riet ruling indeed went one step further, as it considered authorisation policy in the case of non-hospital care versus hospital care. Müller-Fauré was another case regarding dental treatment which had been purchased abroad without prior authorisation, and for which reason the competent institution refused to reimburse the costs. Van Riet, on the other hand, had purchased hospital care at a Belgian hospital without prior authorisation. The Belgian hospital was able to provide the specific treatment much sooner than it could be offered in the Netherlands, and the case thus concerned the topical issue of waiting lists. In both cases, the Dutch sickness fund refused to reimburse the medical costs, arguing that the necessary and appropriate medical care could have been obtained in the Netherlands within reasonable time.

The Court restated much of its previous findings. It found that Dutch authorisation policy deterred, or even prevented, insured persons from having healthcare provided by another member state. The national policy thus comprised a barrier to the freedom to provide services. The Court confirmed its reasoning from Smits-Peerbooms, that such a barrier could be justified by the necessity of costcontainment and planning. However, the Court added to its previous rulings that when laying down the criteria upon which such a barrier may be justified, distinction ought to be drawn between hospital care and non-hospital care. The Court thus proceeded one step further in clarifying its reasoning from Decker/Kohll, as well as in the subsequent ruling of Smits-Peerbooms and Inizan. In the case of hospital care, it repeated its conclusions from Smits-Peerbooms, stating that the requirement of prior authorisation was justified on the condition that it was exercised proportionally and that national authorities had no scope for acting in an arbitrary manner. In its press release, the Court explicated its point of view, stating that,

\footnotetext{
25 The Netherlands, Belgian, Danish, German, Spanish, Irish, Italian, Swedish, British, Icelandic and Norwegian governments submitted opinions in the case.
} 
"prior authorisation may be refused only if treatment which is the same or equally effective can be provided to the patient without undue delay in a contracted establishment. National authorities must take account not only of the patient's actual medical condition and, where appropriate, the degree of pain or the nature of the patient's disability, which might, for example, make it impossible or extremely difficult for him to carry out a professional activity, but also of his medical history" (Court Press release, 13 May 2003, no. 36/03, emphasis added).

Concerning non-hospital care, the Müller-Fauré \& Van Riet ruling indeed clarified some of the aspects left open by Decker/Kohll. The Court concluded that a removal of the prior authorisation requirement for non-hospital care was not likely to,

"give rise to patients travelling to other countries in such large number, despite linguistic barriers, geographic distance, the cost of staying abroad and lack of information about the kind of care provided there, that the financial balance of the Netherlands social security system would be seriously upset and that, as a result, the overall level of public-health protection would be jeopardised - which might constitute proper justification for a barrier to the fundamental principle of freedom to provide services (para. 95 of the judgement, emphasis added).

The Court thus reasoned contextually, considering the political arguments in the light of their socioeconomic background, and refused the national justification for maintaining the control instrument of prior authorisation in the case of non-hospital care. Furthermore, the "might" in the last sentence indicates that what ultimately justifies a barrier to the freedom to provide services has by no means been finally settled, but is likely to be subject to further clarification in future cases.

Whereas the vast majority of member governments initially rejected the applicability of the Decker/Kohll procedure ${ }^{26}$, the Müller-Fauré \& Van Riet ruling has not left much margin in which to continue denying that internal market rules generally apply to non-hospital healthcare. The Court's conclusions must impact on the health policies of the large majority of member states:

"it has not been established that removal of the requirement for prior authorisation would undermine the essential characteristics of the Netherlands sickness insurance scheme. The principle of freedom to provide services therefore precludes legislation such as the Netherlands legislation, which requires the insured to obtain prior authorisation, even under a benefits-in-kind scheme, in the case of non-hospital care provided in another Member State by a non-contracted provider" (Court Press release, 13 May 2003, no. 36/03, emphasis added).

\footnotetext{
${ }^{26}$ Only Luxembourg, Denmark and Belgium amended their legislation as a consequence of the Decker/Kohll rulings. Prior to the 1998 case-law, Austria had entitled socially insured persons to reimbursement of healthcare from a noncontracted provider in Austria as well as abroad (Mossialos and Palm 2003: 12).
} 
The Müller-Fauré \& Van Riet case is another case in a recent cluster of case-law, where the Court has made decisive steps on a path to European healthcare integration. Legal action has driven integration to the fore in a policy area that formerly was considered to be the sole competence of the member states, but where the supreme status and dynamic interpretations of Community principles have compromised this very same competence.

\section{Patient Mobility and Healthcare Developments in the European Union}

Considering the institutionalised rights in its practical, societal context, patient mobility has thus far remained relatively low. As the table below demonstrates, patients have rarely requested treatment abroad.

Table 1: Number of People Requesting and Obtaining Prior Authorisation for Treatment Abroad in Selected Member States

\begin{tabular}{|l|l|l|l|}
\hline & Year & $\begin{array}{l}\text { No of authorisation } \\
\text { requests }\end{array}$ & $\begin{array}{l}\text { No of authorisation } \\
\text { granted }\end{array}$ \\
\hline Austria & Per year 1996-2002 & Not available & 850 \\
\hline Belgium & Per year 1996-2000 & Not available & 2000 \\
\hline Denmark & Per year 1996-2000 & $40-50$ & $25-35$ \\
\hline & $200 \bullet^{\star}$ & Not available & 70 \\
\hline & $2001^{\star}$ & Not available & 75 \\
\hline Finland & 2001 & Not available & 9 \\
\hline & 2002 & Not available & 4 \\
\hline France & Per year 1996-1999 & 310 & 197 \\
\hline Ireland & Per year 2000-2001 & 600 & Not available \\
\hline Italy & 1999 & Not available & 16280 \\
\hline Luxembourg & 1998 & 7130 & 7082 \\
\hline & 2001 & 11751 & 11506 \\
\hline Portugal & 2001 & 260 & 246 \\
\hline Spain & 2001 & Not available & 651 \\
\hline Sweden & Per year 1996-2000 & Not available & 20 \\
\hline & 2002 & 6 & 0 \\
\hline United Kingdom & Per year 1996-1999 & 800 & 600 \\
\hline & 2000 & 1100 & Not available \\
\hline & 2001 & 1134 & Not available \\
\hline
\end{tabular}

(Sources: Palm et al,. 2000: 44-62; Mossialos et al,. 2002: 85; Commission Staff Working Paper 2003)

\footnotetext{
- Authorisation granted for treatment abroad in general and not only within the EU.
} 
The figures on people requesting and obtaining treatment abroad are based on three different sources, of which the most recent data are provided in the Commission Staff Working Paper. These figures are incomplete and only listed for the member states that have provided data. The table demonstrates that we lack sufficient quantitative data on patient mobility in Europe. On the basis of available data, however, we see that the member states differ significantly regarding the extent to which they grant prior authorisation to treatment abroad. The health systems in Luxembourg and Italy have integrated the health supply of other member states much more significantly than for example their northern counter parts, where healthcare remains territorialized. In general, however, cross border healthcare within the European Union only amounts to a negligible part of the total health expenditures in the EU, in 1998 representing no more than $0.50 \%$ of total health expenditures (Palm et. al., 2000; Vollard 2004).

However, the figures above mirror patient mobility in the very wake of ECJ litigation. The precedent established through the case-law will need to be transposed into national legislation and adopted in administrative practices and patients will need to be informed of their rights before the political impact of legal integration will become measurable. Nevertheless, Denmark provides an example of what could be expected. The member state was one the few which revised parts of the national health policy in response to the Decker and Kohll cases and which later adjusted a national health reform, addressing the problem of waiting lists, brining it into compliance with the principles generated in the case of Smits and Peerbooms (Martinsen forthcoming). As seen in the table above, Denmark has experienced a recent increase in the authorisation of treatment provided abroad.

Should member states not respond in accordance with the jurisprudence of the European Court, patients and private or public foreign hospitals are likely to mobilise domestically and invoke their intra-European rights (Börzel 2000).

Furthermore, the line of judgements has established a platform from which new initiatives regarding European healthcare have emerged. In the first half of 2004, proposals have been formulated and decisions have been taken. In the respective order of judicial activism, Commission initiatives, and initial political decision-making, the contours of the European health market have been patched. 
Although the European Court of Justice has clarified key aspects of the conditions under which the costs of foreign healthcare may be reimbursed, many questions remain open as to how to access and integrate the healthcare supply of other member states. Together with health ministers and civil servants from the national administrations, the Commission has entered into a process of reflection concerning patient mobility and healthcare. The reflection group has recently communicated its response on the matter. ${ }^{27}$ This communication provides rich example of what could be expected in the future. Healthcare and patient rights within the European Union have shifted from a mere 'side effect' of the free movement principles to a stated priority with an explicit long-term strategy. The communication declares the commitment to ensure patient rights, provide legal certainty, and enable a better use of health resources within the EU as a whole. The Commissioner for health and consumer protection, David Byrne, furthermore stressed the broader objectives of the communication:

"EU law gives patients the right to go for treatment in other Member States. But exercising that right can prove difficult. A central aim of our proposal is to explain patients' rights more clearly and ensure they have the information they need to make use of those rights. My final goal is to achieve a European Charter of patients' rights to which everyone can refer" (Commission Press Release, 21 April 2004).

A remarkable aspect of the communication from the reflection group is that this expansive and ambitious reading of Community law is referred to as if constituting an already materialised fact, termed as "existing rights to healthcare under Community law" (COM 2004: 2-3 \& 7).

"The European Union provides freedoms for citizens to seek healthcare in other Member States, as confirmed by the European Court of Justice. Regarding reimbursement of healthcare costs when patients have sought medical treatment in another Member State, the Court of Justice has clarified the conditions under which they may be reimbursed. Accessing healthcare depends on having the right information regarding the quality, availability and appropriateness of different services, and to have clarity over the procedures to be followed" (COM (2004) 301:

2, emphasis added).

The ambitions set out in the communication and declared by the Commissioner for health are undoubtedly high. The objective to equip the European citizen with access to foreign health supply must result in an array of different initiatives aiming to settle the relationship between Community law and national competencies and policies, between supranational and national healthcare rights.

\footnotetext{
${ }^{27}$ Communication from the Commission, COM (2004) 301, 20 April 2004. Follow-up to the high-level reflection process on patient mobility and healthcare developments in the European Union.
} 
To fulfil the long term strategy is, however, formulated as 'an essential endeavour', presented as a logical chain, where means and aims bind into one another:

"Achieving these aims will be a long-term and complex project, and may require further proposals in the future. It is nevertheless an essential endeavour. Over time this strategy will repay dividends in better health and quality of life. It will contribute to better use of the resources invested in health systems across Europe. It will promote greater economic growth and more sustainable development for the Union as a whole. And most tangibly for citizens, it will bring concrete benefits for European integration closer to people in their daily lives" (COM (2004) 301: 3).

The vision embedded in this wider strategy is difficult to argue against in a Union seeking its social self as well as seeking to increase its appeal to the peoples of Europe. However, its implementation will irrevocably reduce the political autonomy to decide on the consumption and, depending on future evolvement, the content of healthcare policies.

The content of the recent cluster of case-law and the communication is further concretised in the Commission's proposal for a Directive on services in the internal market. ${ }^{28}$ In the light of the Court's decisions, article 23 of the new directive proposes 1) an internal market for non-hospital care, where the patient has a right to seek treatment in another member state without prior authorisation and subsequently have the costs reimbursed by the competent national institution, 2) a right to hospitalisation in another member state, provided that the member state of affiliation offers the same treatment, and that authorisation has been granted beforehand. The national discretion to decide on authorisation has, however, been reduced, since the provision clarifies that the patient is entitled to authorisation if the national health system cannot provide the care within a medically acceptable time limit considering the individual health conditions.

The directive proposal thus aims to codify the Court's interpretation of the scope and limits of intraEuropean healthcare.

Furthermore, the accessibility of European health has been clearly improved on a different dimension. After June $1^{\text {st }}$ 2004, all European citizens travelling within the European Economic

\footnotetext{
${ }^{28}$ COM (2004) 2, 5 March 2004. Proposal for a Directive of the European Parliament and of the Council on Services in the Internal Market..
} 
Area $^{29}$ for private or professional reasons can, upon request, receive a European health insurance card. This card entitles the holder, in accordance with the legislation of the member state in which one is temporarily staying, to any benefits-in-kind that have become necessary for medical reasons during that stay. The card replaces the previous forms granting the same right. ${ }^{30}$ The symbolic and practical value of a uniform card within the EEA is undoubtedly high. The card replaces former application procedures, increases the transparency and accessibility of foreign healthcare rights, and has been launched as "more Europe in your pocket". However, the card does not replace the authorisation procedure analysed in the previous sections. A person travelling to another member state for the purpose of receiving medical care is not entitled to healthcare on the basis of the insurance card. This form of 'purposive' health treatment abroad continues to require prior authorisation, and the right thereto must be granted by the traditional authorisation form. ${ }^{31}$

Two other initiatives are likely to contribute to the content and reach of the European health market. As part of the wider strategy, a separate communication sets out the intention to extend the 'open methods of coordination' to healthcare and long-term care. Best practices and the evaluation of national strategies will then be discussed and examined through the Community tool of soft-law. A further communication sets out an 'e-health action plan', which intends to use information technology to help improve access and quality for health services within the European Union. Despite the fact that communications are likely to be delayed before they are transposed into real policy-commitment, the picture is clear.

The intension to inform the European citizen regarding his/her cross-border rights is in itself likely to spur the integration process. Furthermore, patient mobility and demands for cross-border care are likely to be further stimulated by contemporary facts such as waiting lists, the increased general cross-border movements by European citizens, and growing integration in border regions (Mossialos and Palm 2003: 7). With increased information about healthcare options across borders, patients will try their rights before national administrations, European law will be tried before

\footnotetext{
${ }^{29}$ That is, the European Union as well as Norway, Iceland, Liechtenstein. The agreement also includes Switzerland.

${ }^{30}$ The card replaces the E111 form used by tourists; E110 used by international road transporters; E128 used by students and people working in another member state; and E119 used by people registered as unemployed and seeking work in another member state.

${ }^{31}$ I.e. form E112. The rights and obligations according to the new European health insurance card can be found at http://europa.eu.int/comm/employment_social/healthcard/index_en.htm.
} 
national courts, and eventually the ECJ will be requested to clarify new aspects. In this way, should member states be reluctant to implement rights, then they may simply be bypassed by 'transnational constituencies' (Pollack 1998: 221-222). 'Transnational constituencies' between the European Court, national courts and the European citizens acting as litigants constitute a means of counterbalancing the influence of member states in the legal integration process. The stronger the link between the supranational organisation and its constituencies, the more institutionalised supranational rules become and the greater the costs of non-compliance by the member states. In this way, the rights of European patients and hence their mobility are likely to be spurred of their own accord.

\section{Concluding Remarks}

Recent legal deductions have taken a decisive step towards an internal market for non-hospital care, as well as having compromised the authority of the member states when deciding on granting authorisation for hospitalisation abroad. Politics has yet to interfere thus far. Voices have been heard, but not in unison. In the absence of political guidance, the Court has continued to decide autonomously on the scope and limits of an internal health market.

The political impact of this specific process of integration through law is, however, clear. The process fundamentally compromises the political autonomy to demarcate healthcare within own borders. The interpretations of the European Court have provided exit options for EU patients (Vollard 2004), and the Court has established an alternative to insufficient national health services. The application of internal market principles means that both the national monopoly to supply public healthcare and the territorialisation thereof are essentially challenged.

The consequences are political, and the response to legal integration need be political as well. The legal institutionalisation of supranational rights intervenes in the social contract between the nation state and its citizens. The performance of healthcare systems is a key component of governmental legitimacy (Vollard ibid.), but capacity problems have thus far relied on national solutions. An EUbased alternative has now been provided. Whether this will significantly increase patient mobility or not essentially depends on the political response and whether national health services satisfy public demands. In this way, political autonomy is also reduced. With an EU health dimension, national health systems must satisfy the demands of citizens who, from a supranational locus of rights, have 
been granted exit options, and thus will compare the national supplies with those on the other side of the border and request on this behalf. The full-scale political impact remains to be seen and depends on patient mobilisation, political response, national implementation of supranational rights, and not least further judicial clarifications.

As for the relation between law and politics, the question remains how healthcare integration could become the offspring of free movement provision and despite a fairly ambiguous and vague Treaty text and why politics has not restrained the expansive judicial reading of Community principles?

The integration process, as depicted above, demonstrates the ability of the European Court of Justice to apply the fundamental provision of free movement to a policy field, which not so long ago was held largely insulated from Community law. First of all, it has done so on the basis of the Treaty as an 'incomplete contract', where the "meaningful uncertainty as to the precise nature of the commitment made" (Stone Sweet 2004: 24) provides the necessary room from further institutionalisation onto and within a new policy field. The subsequent course of institutionalisation is designed by ambitious and purposive judicial interpretations, proving that rules and rights in the European Union are indeed indeterminate (Stone Sweet 2004; de Búrca 2005) and thus possess a dynamic meaning in consequence of a dynamic legal order. The integration dynamic stands as a result of a constant revelation of the insufficiency of the established rules and a Court that is requested to apply, interpret and clarify the meaning of Community law. In this way, the context for subsequent actions continuously shifts (Stone Sweet et al. 2001). Secondly, in part, the premises of integration through law originate from the complexity of the European polity and from the case-tocase construction of meaning formulated by judicial decision-making. In a political and legal entity where the issue-density between policy fields and principles is high and where the limits of rational institutional design ${ }^{32}$ are evident, complexity is one premise extending the scope of manoeuvre of the Court. Rather than the "mask of law" (Burley and Mattli 1993), it appears as though the opacity of legal integration itself shields it from political intervention (Rasmussen 1998: 539-541). It may not be judicial activism, which is difficult for politics to see through and counterbalance, but the facts that a) EU law evolves through piecemeal interpretations, that b) the consequences and course thereof are difficult to predict, and that c) the Court is capable of acting both cautiously and

\footnotetext{
${ }^{32}$ For the theoretical elaboration of the limits of rational institutional design, see Pierson 2000.
} 
ambitiously at one and the same time. ${ }^{33}$ Thirdly, although the ECJ has no autonomous capacity to pursue integrative agendas and although its rate of success ultimately depends on the political response to its decisions, it is clear that when politics must counterbalance judicial decision-making, it finds its own logic working against it. Politics and law appear to be two distinct spheres that respond to very different logics (Alter 1998; 2001). Lawyers and judges evidently take a long-term interest in the evolution of law, whereas politicians tend to have short-term interests and react to judicial activism for its immediate impact and not for its potential impact. For lawyers and judges, case law is interesting for its establishment of precedent. For politicians, the rather short-term material impact of a case is what renders it significant - or not. In part, non-action is explained by the restricted time horizon of political actors (Pierson 1996). Fourthly, a different explanation of non-action is that politicians tend to refuse that controversial litigation also applies to their national systems. By declining the multilateral effect of Community law, national policies are shielded from supranational interference - at least in the short to medium run (Martinsen 2004). Fifthly, the institutional barriers confronting member government, should they wish to restrain the Court, have become considerably higher by enlargement. From the opinions submitted by the member states, it is clear that a majority of member states disagreed with the Court's application of the principle on the free movement of services to healthcare policies; however, member states would need to act in unison if they should rule in the Court through the means of a Treaty amendment. Only a single member state out of 25 needs to agree with, or simply not pay sufficient interest to, the legal deductions of the Court, and it is impossible for politics to sanction the legal course of integration. Even though the institutional barriers to collectively overturn the Court's interpretations of the words of the Treaty were certainly high before May 2004, the autonomy and authoritative position of the Court have increased considerably as a consequence of enlargement.

The depicted course of healthcare integration substantiates that Community law is a supranational source of individual rights, which through the empowerment of the European patients augments enforceable and material meaning to the skeleton of European citizenship. This development has taken place at the threshold to a Constitution for Europe. What has occurred on the basis of an ambiguous and rather vague Treaty basis suggests that with the charter of fundamental rights inserted in the Constitution, we should expect much more from social Europe in the future.

\footnotetext{
${ }^{33}$ For this ambiguity of the Court's actions and its integrative course, see Craig and de Búrca 1998: 78-79.
} 


\section{References}

Alter, Karen (1998). "Who are the 'Masters of the Treaty'? European Governments and the European Court of Justice”, International Organization, 52: 1, 121-147.

Alter, Karen (2001). Establishing the Supremacy of European Law. The Making of an International Rule of Law in Europe. Oxford: Oxford University Press.

Börzel, Tanja A. (2000). "Why There is No "Southern Problem". On Environmental Leaders and Laggards in the European Union”, Journal of European Public Policy, 7: 1, 141-162.

Burley, Anne-Marie, and Walter Mattli (1993). "Europe Before the Court: A Political Theory of Legal Integration", International Organization, 47: 1, 41-76.

Commission Staff Working Paper (2003). Report on the Application of Internal Market Rules to Health Services. Implementation by the Member States of the Court's Jurisprudence. Brussels.

Craig, Paul, and Gráinne de Búrca (1998). EU Law - Text, Cases and Materials. Oxford: Oxford University Press.

De Búrca, Gráinne (2005). "Rethinking Law in Neofunctionalist Theory”, Journal of European Public Policy, 12:2, 1-17.

Eckstein, Harry (1975). "Case Study and Theory in Political Science” in Greenstein, Fred I., and Nelson W. Polsby W. (eds.) Strategies of Inquiry. Addison-Wesley Publishing Company, 79-137.

Eichenhofer, Eberhard (1999). “Aspekte Europäische Gesundheitspolitik - Der Zugang zu Leistungen der Kranken- und Pflegeversicherung der EU-Bürger - Situation des Koordinierungsrechts und Veränderungsbedarf” in Gerhard Igl (Hrsg.) Europäische Union und gesetzliche Krankenversicehrung - Status und Entwicklungen der Gesundheitspolitik in der EU. Wiesbaden: Verlag Chmielorz GmbH, 45-60. 
Eichenhofer, Eberhard (1999b). "Das Europäische koordinierende Krankenversicherungsrecht nach den EuGH-Urteilen Kohll und Decker", Vierteljahresschrift für Sozialrecht 2, 101-122.

Eichenhofer, Eberhard (2001). Sozialrecht der Europäischen Union. Berlin: Erich Schmidt Verlag $\mathrm{GmbH} \& \mathrm{Co}$.

Everson, Michelle (1995). "The Legacy of the Market Citizen" in Shaw, Jo, and Gillian More (eds.), New Legal Dynamics of European Union. Oxford: Clarendon Press), 73-90.

Ferrera, Maurizio (2003). "European Integration and National Social Citizenship: Changing Boundaries, New Structuring ?”, Comparative Political Studies, 36: 6, 611-652.

Hartley, Trevor (1998). The Foundation of European Community Law. Oxford: Clarendon Press.

Hervey, Tamara (2000). “Social Solidarity: A Buttress Against Internal Market Law?” in Jo Shaw (ed.), Social Law and Policy in an Evolving European Union. Oxford: Hart Publishing, 31-49.

Kötter, Ute (2000). "Marktsteuerung im Gesundheitswesen und europäische Markt- und Wettbewerbsordnung", Sozialer Fortschritt 49: 2/3, 27-31.

Langer, Rose (1999). "Der Beitrag des Europäischen Gerichtshofs zu den gemeinschaftsrechtlichen Gestaltungsvorgaben für das Sozialrecht" in Ingwer Ebsen (Hrsg.), Europarechtliche Gestaltungsvorgaben für das deutsche Sozialrecht - Freizügigkeit, wirtschaftliche Grundfreiheiten und europäisches Wettbewerbsrecht als Grenzen sozialstaatlicher Souveränität. Baden-Baden: Nomos Verlagsgesellschaft, 43-56.

Maduro, Miguel P. (1999). „Striking the Elusive Balance Between Economic Freedom and Social Rights in the EU“ in Phillip Alston (ed.), The EU and Human Rights. Oxford: Oxford University Press, 449-473.

Martinsen, Dorte S. (2003). Who has the Right to Intra European Social Security? From Market Citizens to European Citizens and Beyond. EUI Working Paper, Department of Law 2003/13, 1-48. 
Martinsen, Dorte S. (2004). European Institutionalisation of Social Security Rights: A Two-layered Process of Integration. Ph.D. Thesis, European University Institute, 1-392.

Martinsen, Dorte S. (forthcoming). "The Europeanisation of Welfare - the Domestic impact of Intra-European Social Security", accepted for publication in Journal of Common Market Studies.

Maydell, Bernd von (1999). "Auf dem Wege zu einem gemeinsamen Markt für Gesundheitsleistungen in der Europäischen Gemeinschaft", Vierteljahresschrift für Sozialrecht, 1, 3-19.

Mossialos, Elias, Martin McKee, Willy Palm, Karl Beatrix, and Franz Marhold (2001). The influence of EU law on the social character of health care systems in the European Union. Brussels: Report submitted to the Belgian Presidency of the European Union.

Mossialos, Elias, Martin McKee, Willy Palm, Karl Beatrix, and Franz Marhold (2002). EU Law and the Social Character of Health Care. Brussels: Peter Lang.

Mossialos, Elias, and Willy Palm (2003). "The European Court of Justice and the free movement of patients in the European Union", International Social Security Review, 56: 2, 3-29.

Neumann-Duesberg, Rüdiger (1999). “Grenzüberschreitende Behandlungsleitungen - die Praxis in der gesetzlichen Krankenversicherung”, 11. Bonner Europa-Symposion - Grenzüberschreitende Behandlungsleistungen in Binnenmarkt. Rheinische Friedrich-Wilhelms-Universität Bonn: Zentrum für Europäische Wirtschaftsrecht, 21-38.

Novak, Meinhard (1998). "EG-Grundfreiheiten und Europäisches Sozialrecht”, Europäische Zeitschrift für Wirtschaftsrecht, 12, 366-369.

Palm, Willy, Jason Nickless, Henri Lewalle, and Alain Coheur (2000). Implications of Recent Jurisprudence on the Coordination of Health Care Protections Systems. Summary Report Produced 
for the European Commission Directorate-General for Employment and Social Affairs Brussels: Association Internationale de la Mutualite (AIM).

Pierson, Paul (1996). "The Path to European Integration - A Historical Institutionalist Analysis", Comparative Political Studies, 29: 2, 123-163.

Pierson, Paul (2000). "The Limits of Institutional Design: Explaining Institutional Origins and Change", Governance, 13: 4, 475-501.

Pollack, Mark A. (1998). "The Engines of Integration? Supranational Autonomy and Influence in the European Union" in Sweet, Alec S and Wayne Sandholtz (eds.), European Integration and Supranational Governance. Oxford: Oxford University Press, 217-250.

Rasmussen, Hjalte (1998). EU-ret i kontekst. København: GadJura.

Shaw, Jo (1997). „European Citizenship: The IGC and Beyond”, European Integration online Papers (EIoP), 1: 3, http://eiop.or.at/eiop/texte/1997-003a.htm, 1-23.

Stone Sweet, Alec, Neil Fligstein, and Wayne Sandholtz (2001). "The Institutionalisation of European Space" in Stone Sweet, Alec, Wayne Sandholtz, and Neil Fligstein (eds.), The Institutionalisation of Europe. Oxford: Oxford University Press, 1-29.

Stone Sweet, Alec (2004). The Judicial Construction of Europe. Oxford: Oxford University Press.

Vollard, Hans (2004). "Solidarity, Territoriality, and Healthcare: Cross-National Policy Learning in Europe", in D. Levi-Faur, E. Vigoda-Gadot (eds.), International Public Policy and Management: Policy Learning beyond Regional, Cultural, and Political Boundaries. New York: Marcel Dekker. 267-295. 